\title{
Peran Kearifan Lokal Masyarakat Jawa Untuk Melestarikan Batik Tradisi di Girilayu, Karanganyar, Indonesia
}

\author{
Desy Nurcahyanti ${ }^{1}$, Agus Sachari $^{2}$, Achmad Haldani Destiarmand ${ }^{3}$ \\ ${ }^{1}$ Program Studi Doktor Ilmu Seni Rupa dan Desain, Fakultas Seni Rupa dan Desain \\ Institut Teknologi Bandung, Jl. Ganesha No. 10 Bandung 40132 Indonesia \\ ${ }^{2,3}$ Fakultas Seni Rupa dan Desain, Institut Teknologi Bandung \\ Jl. Ganesha No. 10 Bandung 40132 Indonesia
}

${ }^{1}$ desynurcahyanti@students.itb.ac.id

Rangkaian proses rumit yang menghasilkan nilai filosofi tinggi pada batik mulai ditinggalkan oleh masyarakat pembuatnya yakni para perajin batik. Fenomena menurunnya minat generasi muda untuk melanjutkan pembuatan batik tradisi di sentra-sentra batik merupakan masalah yang harus dipecahkan dari berbagai latar belakang, di antaranya secara sosial dan budaya. Solusi dan alternatif pemecahan masalah dengan menggunakan konsep kearifan lokal perlahan diterapkan kembali oleh para perajin batik di Girilayu. Rumusan masalah penelitian antara lain: 1) apa faktor yang menyebabkan menurunnya pembuatan dan fungsi batik tradisi di Girilayu?, 2) apa peran kearifan lokal masyarakat Jawa di Girilayu untuk melestarikan batik tradisi?, dan 3) bagaimana cara penerapan kearifan lokal masyarakat Jawa di Girilayu?. Tujuan penelitian dilaksanakan antara lain: 1) mendeskripsikan penyebab menurunnya pembuatan serta penggunaan batik tradisi di Girilayu, 2) mengetahui peran kearifan lokal masyarakat Jawa untuk melestarikan batik tradisi di Girilayu, dan 3) menguraikan cara penerapan kearifan lokal dalam melestarikan batik tradisi di Girilayu; sehingga bermanfaat untuk rumusan efektifitas kearifan lokal sebagai sumber pelestarian tradisi terutama batik. Metode etnografi dipergunakan dalam penelitian ini. Teori kebudayaan superorganik dari Melville J. Herkovits dipergunakan untuk panduan menemukan korelasi antara peran kearifan lokal dengan pelestarian batik tradisi. Teknik pengambilan data yakni wawancara mendalam pada para perajin batik di Girilayu, tokoh, dan pakar batik sebagai data primer; serta studi pustaka referensif sebagai data sekunder. Pendekatan antropologis dipergunakan sebagai instrumen analisis berdasarkan realitas sosial dan budaya. Penelitian ini menemukan bahwa peran kearifan lokal masyarakat Jawa dalam melestarikan batik tradisi di Girilayu dapat berjalan efektif melalui dukungan pendidikan keluarga dan sekolah secara intensif.

Kata kunci: batik tradisi, Girilayu, kearifan lokal, masyarakat Jawa

\section{The Role of Javanese Local Wisdom to Preserve Tradition Batik of Girilayu, Karanganyar, Indonesia}

A series of sophisticated processes which produces high philosophical values on batik seems to be deserted by its makers' community, i.e. batik artists. The declining interest of younger generation to continue making batik tradition in batik centers is a problematic phenomenon which needs solution from various backgrounds, for instance from social and cultural sectors. Some batik artists in Girilayu gradually reapply the cocept of local wisdom as the solutions to this problem. This research aims to describe the way Girilayu's batik artists apply values and meanings of local wisdom. It can be applied persistently and bring beneficial advantages for the preservation of tradition batik; that useful for the formulation of local wisdom effectiveness as a preserving tradition source, especially batik. This study used ethnographic methods. Superorganic culture theory from Melville J. Herskovits was used to find a correlation between local wisdom role and tradition batik preservation. Data collection techniques namely in-depth interviews with batik artisans in Girilayu, figures, and batik experts as primary data; and reference library studies as secondary data. Anthropological approach was used as a basic analysis instrument on social and cultural realities. This study found that the role of Javanese local wisdom in preserving tradition batik in Girilayu can run effectively through intensive support from family and school education.

Keywords: tradition batik, Girilayu, local wisdom, Javanese society

Proses Review : 1 - 20 Mei 2020, Dinyatakan Lolos: 29 Mei 2020 


\section{PENDAHULUAN}

Produk budaya merupakan identitas negara yang mampu merepresentasikan tradisi.Indonesia telah diakui sebagai negara dengan kekayaan dan keragaman produk budaya yang masing-masing memiliki makna filosofis. Nilai dan norma sebagai pegangan hidup bagi masyarakat merupakan referensi pembentuk keragaman produk budaya (Cynthia, 2011). Serangkaian nilai dan norma tersebut bersifat dinamis, mampu menyesuaikan zaman yang memiliki keniscayaan untuk tumbuh, berkembang, dan berubah. Masyarakat memiliki kecenderungan untuk mengikuti perubahan zaman dan mengkonsumsi hasil perkembangannya, yakni teknologi. Tatanan masyarakat dan seluruh aspek pendukungnya mengalami perubahan karena kemajuan teknologi, terlebih di zaman yang disebut revolusi industri 4.0 saat ini. Peran manusia tereduksi oleh mesin, kecerdasan buatan, dan sistem digital. Muncul istilah disrupsi yang beriringan dengan revolusi industri 4.0 saat ini.Kegagalan manusia untuk mengelola posisi dan tetap berdaya di zaman posmodern yang serba cepat adalah penyebab disrupsi.Masyarakat dituntut untuk kreatif, mampu bertahan dengan panduan hidup yang sesuai, dan memanfaatkan kecanggihan teknologi secara cerdas. Mereka yang mampu mengkombinasikan antara konsep, kreatifitas, ketekunan, dan kerja cerdas dengan bijak yang akan memenangi persaingan. Kebijaksanaan yang dapat dijadikan pedoman dan panduan terdapat pada kearifan lokal (Situngkir, 2016).

Abstraksi konsep masyarakat tradisi sebagai panduan cara hidup bersumber dari kebijaksanaan (kompromi kontemplatif hasil perenungan mendalam) dan kebijakan (ketetapan dari kesepakatan) leluhuryang disebut kearifan lokal (Endraswara, 2018). Esensi kearifan lokal yang dipahami masyarakat tertuang dalam tiga wujud, yakni mentifak (pola pikir), sosiofak (norma dan nilai dalam masyarakat), dan artefak (benda pendukung kebutuhan hidup). Tiga hal tersebut saling terkait, terhubung, dan berkorelasi. Pola pikir dan norma yang diyakini oleh sebuah masyarakat dapat terlihat dari wujud artefaknya. Sebaliknya, artefak merupakan petunjuk norma dan pola pikir yang diyakini oleh suatu masyarakat (Tabrani, 2012: 16-22, 178-184). Masyarakat yang tinggal di pesisir memiliki karakter dan wujud artefak berbeda dengan masyarakat di dataran rendah dan di pegunungan. Kondisi iklim dan geografis secara alami mendorong manusia untuk melakukan sistem adaptasi dan menciptakan produk budaya sebagai mekanisme pertahanan khusus.Kearifan lokal mengandung unsur pemecah masalah untuk menjawab kesulitan manusia ketika menyesuaikan kondisi lingkungan. Mobilitas dan perpindahan suatu masyarakat akan membawa serta wujud kearifan lokal dan meninggalkan jejak kekhasannya, kemudian tercipta akulturasi budaya. Kearifan lokal pada artefak dominan terdapat di benda kebutuhan primer manusia, yakni sandang, pangan, dan papan; terwujud melalui proses, bentuk, nilai, corak, dan fungsi.Perubahan zaman telah merubah alur tersebut menjadi sebaliknya.
Saat ini artefak digunakan sebagai perantara untuk medium pesan dan ekspresi artistik dengan material baru.

Bertutur dalam pengertian harfiah, menjadi cara dasar bagi manusia untuk menyampaikan pesan, petuah, dan nasehat pada pihak lain. Pada masyarakat nusantara awal sebelum Indonesia merdeka; bertutur melalui cerita dan dongeng menjadi bentuk komunikasi untuk menyampaikan pesan secara non formal dalam keluarga; kemudian terbentuk sebuah budaya tutur, bercerita, dan mendongeng. Bertutur merupakan cara berkomunikasi mudah dan alami, tetapi memiliki kelemahan. Pesan atau cerita yang disampaikan akan memiliki kualitas dan maksud yang dipahami secara berbeda, jika diulang dengan komponen berbeda. Komponen yang dimaksud adalah pelaku, gaya, irama, suasana, dan penerima pesan. Pendokumentasian diperlukan dengan tujuan pesan dapat dipelajari ulang dalam jangka panjang dengan maksud sama sebagaimana penutur pertama menyampaikan. Format tulis melalui beragam media merupakan cara mengabadikan tutur supaya dapat dipahami oleh generasi berikutnya tanpa mengurangi inti cerita. Beberapa pesan terabadikan dalam relief-relief candi dan lembar-lembar manuskrip atau naskah kuno.Sebagian cerita masih diwariskan dalam format tutur secara turunmenurun dari generasi ke generasi, yaitu tradisi lisan.

Masyarakat Jawa Tengah memiliki tradisi lisan sebagai bentuk budaya dan media dalam menyampaikan pesan; selanjutnya bertransformasi melalui beragam wujud artefak.Cara penyampaian pesan menggunakan pemilihan kalimat penuh simbol, perlambang, dan kiasan. Wong Jowo atau masyarakat Jawa memiliki kepekaan batin tinggi dan berkarakter halus, sehingga cara menyampaikan pesan pun menggunakan kalimat tidak langsung. Kelemahan cara penyampaian pesan samar atau tidak langsung yakni sulit dimengerti oleh pihak lain yang kurang paham karakter masyarakat Jawa; karena harus menginterpretasikan ulang maksud kalimat tersebut. Kelebihannya adalah mampu menghindarkan dari konfrontasi dengan lawan bicara. Sikap demikian merupakan bentuk kearifan lokal masyarakat yang disebut bijak Jawa; cara menyikapi dan berkomunikasi khas Jawa yang bijaksana. Kearifan lokal menjadi panduan nilai dan norma yang penting bagi masyarakat Jawa; dan memiliki peran sebagai sarana penjaga harmoni antara manusia dengan alam secara fisik serta metafisik (Adnyani, 2017). Batik adalah salah satu media ekspresi masyarakat Jawa dalam menyampaikan pesan secara simbolis. Motif batik merupakan kumpulan ornamen stilasi (penggayaan) dengan komposisi estetis yang bertujuan untuk menyampaikan pesan, cerita, dan nasehat bijak.

Batik tradisi saat ini mengalami permasalahan terkait keberlanjutan oleh generasi penerusnya; khususnya pewarisan keahlian membatik. Era keterbukaan informasi dan perkembangan teknologi telah menawarkan alternatif aktifitas yang lebih menarik selain membatik. Proses batik memiliki rangkaian panjang dan detail, tidak dapat diker- 
jakan sambil lalu. Tahapannya harus dilalui secara baik, tidak boleh ditawar dengan mengurangi atau mengakali proses (membatik tidak berdasarkan urutan), karena akan mempengarungi kualitas serta makna keseluruhan karya. Salah satu alternatif yang dipilih oleh generasi penerus perajin batik tersebut yakni membuat batik dengan proses non manual, menggunakan mesin cetak atau digitalisasi. Proses mesin dan digital menyebabkan hasil akhir tidak dapat disebut sebagai kain batik, tetapi tekstil atau kain dengan motif batik. Kain batik adalah kain yang diberi hiasan ornamen motif batik dengan teknik tutup celup malam panas menggunakan canting atau cap tembaga. Kekhawatiran para pembatik senior atau yang berusia lanjut cukup beralasan, karena generasi penerus tidak berminat belajar membatik atau memilih alternatif proses di luar batik tradisi untuk memvisualisasikan motif-motif batik tanpa mempertimbangkan kepedulian terhadap keberlanjutan tradisi.

Para pembatik di Girilayu, Karanganyar, Jawa Tengah merupakan sentra batik tradisi yang mengalami masalah keberlanjutan keahlian membatik pada generasi penerusnya. Kesempatan pelatihan yang diberikan oleh pemerintah untuk memperdalam keahlian membatik dari segi proses dan desain motif mampu menggerakkan para pembatik untuk berinovasi mengembangkan motif baru dan motif batik ikon untuk Sentra Batik Girilayu. Hal tersebut menggerakkan para generasi penerus untuk mulai belajar membuat motif baru dan membatik. Nasehat, pesan, dan cerita bersumber kearifan lokal masyarakat Girilayu menjadi inspirasi pembuatan motif kontemporer.Upaya pembatik Girilayu tersebut menarik diteliti. Pembatik Girilayu secara tidak langsung telah menciptakan solusi untuk masalah keberlanjutkan keahlian membatik. Penelitian ini bertujuan untuk mengeksplorasi cara masyarakat Girilayu untuk menumbuhkan kesadaran keberlanjutan batik tradisi; dan mendiskripsikan wujud kearifan lokal yang dipergunakan sebagai sumber ide pengembangan desain motif kontemporer. Girilayu dipilih sebagai lokasi penelitian karena memiliki latar belakang pengembangan batik tradisi yang kuat sejak awal pemerintahan Mangkunagara I yakni pemimpin Pura Mangkunagaran; kerajaan kecil setingkat kadipaten atau satu tingkat di bawah Keraton di Surakarta.

Peran kearifan lokal masyarakat Jawa dalam keberlanjutan batik tradisi di Girilayu merupakan pengembangan dari penelitian terdahulu. Topik serupa masih terdapat celah permasalahan untuk dieksplorasi lebih lanjut, yakni perihal peran kearifan lokal pada suatu masyarakat untuk keberlanjutan tradisi. Penelitian-penelitian terdahulu telah membahas kearifan lokal masyarakat Jawa dari aspek kemanfaatannya sebagai sumber inspirasi dalam penciptaan karya seni, desain, dan panduan perumusan kebijakan pemerintah berkaitan dengan hukum; serta cara mereaktualisasi kearifan lokal dengan kondisi masyarakat terkini. Aspek dampak atau akibat dari penerapan lokal pada suatu masyarakat sebagai solusi permasalahan regenerasi tra- disi belum pernah diteliti. Referensi terkait topik kearifan lokal, keberlanjutan (pewarisan, pelestarian), dan tradisi yang digunakan sebagai referensi penelitian terdapat pada makalah, jurnal, dan buku. Makalah berjudul "Menggali Nilai-nilai Kearifan Lokal Budaya Jawa sebagai Sumber Pendidikan Karakter" atau The Javanese Cultural Local Wisdom Values Exploration for Character Buiding Educational Source, menguraikan tentang nilai-nilai luhur yang diperoleh dengan memahami ungkapan yang sering digunakan oleh masyarakat Jawa dalam kehidupan sehari-hari. Hasil penelitian mengungkap bahwa memahami ungkapan Jawa dapat digunakan sebagai sumber pendidikan karakter bersifat universal. Cara pemahaman dapat diterapkan pada peserta didik dengan empat metode, yakni penanaman nilai, keteladanan nilai, fasilitasi nilai, dan keterampilan. Pada "Peranan Kearifan Lokal dalam Pendidikan Karakter" atau The Role of Local Wisdom in Character Building Education, kearifan lokal menjadi objek diskriptif secara universal di wilayah Indonesia.Spesifikasi lokasi khusus atau ruang lingkup tidak disebutkan, sehingga kesimpulan sebatas menyampaikan urgensi keberlanjutan penggunaan kearifan lokal sebagai dasar untuk perumusan pembelajaran pendidikan karakter (Budiyono, 2017: 92-103; Fajarini, 2014: 123-130). Hal serupa disebutkan dalam penelitian "Kearifan Lokal sebagai Modal Sosial dalam Pendidikan Karakter di Sekolah" atauLocal Wisdom as Social Capital in Character Building at School Education, dengan kebaruan pada ruang lingkup penerapan yaitu sekolah, dan posisi kearifan lokal bagi pendidikan karakter sebagai modal sosial (Astuti, 2012: 61-72).

Peran kearifan lokal dalam keberlanjutan tradisi sebagai dampak penerapannya dalam sebuah tradisi masyarakat Jawa justru menjadi anti tesis artikel jurnal Musâwa berjudul "Peran Perempuan dalam Mempertahankan Kebudayaan Jawa dan Kearifan Lokal" atau The Women Role to Preserve Javanese Culture and Local Wisdom. Hasil penelitian pada jurnal tersebut menguraikan bahwa perempuan dalam masyarakat Jawa memiliki kaitan erat dengan upaya mempertahankan kebudayan dan kearifan lokal.Perspektif yang digunakan untuk menjabarkan dipersempit dari aspek bentuk kesenian, adab, feminism, peran perempuan melalui keluarga, isu gender dan agama. Garis besar penjelasan artikel ini adalah peran perempuan Jawa untuk mempertahankan kebudayaan dan kearifan lokal terimplementasi pada aktifitas utama dalam lingkup keluarga sebagai istri dan ibu, serta keterlibatan aktif pada kegiatan sosial di masyarakat (Inawati, 2014: 196-206). Sudut pandang berbeda disajikan pada penelitian berjudul "Bahasa Jawa sebagai Pengungkap Kearifan Lokal Masyarakat Samin di Kabupaten Blora" atau Javanese Language as Samin's Society Local Wisdom Revealers in Blora District, memposisikan kearifan lokal sebagai objek hasil analisis bahasa Jawa yang digunakan oleh masyarakat Samin. Ajaran dan nasehat tentang tata sosial disampaikan masyarakat Samin dalam bahasa Jawa.Secara tidak langsung bahasa sebagai media dalam keberlanjutan kearifan lokal 
(Mardikantoro, 2013: 197-207).

Kearifan lokal didefinisikan secara sederhana pada temuan publikasi ilmiah berjudul "Nilai Kearifan Lokal dalam Batik Tradisional Kawung" atau Local Wisdom Values at The Kawung's Traditional Batik, yakni sebagai tatanan hidup ideal pada masyarakat yang tersirat dan tersurat pada warna, corak, pola, serta fungsi. Kedalaman makna yang terdapat pada motif batik Kawung merupakan hasil akulturasi budaya Jawa, Hindhu, dan Islam yang kaya filosofi. Peran kearifan lokal pada artikel jurnal tersebut tidak disinggung secara langsung, karena fokus permasalahan dipersempit pada nilai simbolis batik motif Kawung secara sosial dan sakral (Pramono, 2013: 134-146). Hal serupa juga menjadi pokok bahasan penelitian lain berjudul "Identifikasi Bentuk-bentuk Kearifan Lokal dalam Sistem Religi Masyarakat Situs Sangiran Studi Kasus Masyarakat Gondangrejo, Karanganyar" atau Local Wisdom Forms Identification in The Sangiran's Site Society Religion System Case Study Gondangrejo Society, Karanganyar. Penelitian tersebut menyimpulkan bahwa masyarakat Sangiran (sampai dengan penelitian diselenggarakan) masih menjaga religiusitas dan melaksanakan aktivitas tradisi sebagai simbol bentuk kearifan lokal (Amanda, 2018: 123-132). Eksplorasi kearifan lokal dalam ranah karya sastra fiksi menjadi pembahasan dari perspektif sistem pemerintahan masyarakat Jawa dalam "Kearifan Lokal Masyarakat Jawa dalam Novel Genduk Sundari Mardjuki" atau Javanese Society Local Wisdom in The Genduk Sundari Mardjuki's Novel (Ningsih, 2018: 1-11). Nilai filosofi tinggi pada batik tradisi terletak pada fungsinya sebagai sumber ajaran pedoman hidup manusia, identitas, religiusitas, dan harmonisasi dengan alam fisik serta metafisik (Herdiana, 2020: 53-62; Qiram, 2018: 79-85; Wahida, 2020: 76-82). Batik seperti seni tradisi lain memiliki nilai filosofis yang bersifat didaktis, humanistis, dan spiritual sebagai indikator kompleksitas kultural sebuah bentuk peradaban serta cerminan suatu tatanan ideal di masyarakat (Kristie, 2019: 57-69; Suarta, 2018: 191-199; Suminto, 2015: 1-12). Batik tradisi saat ini mulai meninggalkan ajaran nilai filosofis, tercermin pada proses pembuatannya yang dilaksanakan atas dasar motif ekonomi, bukan aktivitas serta sarana spiritualitas.

"Upacara Tradisional Jawa: Menggali Untaian Kearifan Lokal" atau Javanese Traditional Ceremony: Local Wisdom Chains Exploration secara jelas membahas detail kearifan lokal dari segi nilai filosofis dan fungsi pada beragam upacara tradisi, seperti labuhan, kelahiran, pernikahan, dan ruwatan. Posisi dan pengaruh kearifan lokal pada buku tersebut tidak disinggung secara langsung (Purwadi, 2005). Sedangkan Mistik Kejawen mempergunakan perspektif peran kearifan lokal tetapi topik bahasan spesifik pada mistik Jawa sebagai keyakinan sistematis pada sebagian besar masyarakat di Indonesia (Mulder, 2005). Alur berpikir yang sama digunakan dalam "Mantra Kidung Jawa: Mengurai yang Lingual hingga Tran- sendental", untuk mengekspos kearifan lokal masyarakat Jawa dalam bentuk primbon (Widodo, 2018). Secara keseluruhan referensi makalah, jurnal, dan buku dengan topik kearifan lokal masyarakat Jawa dari berbagai perspektif masih terdapat celah topik penelitian, yakni peran dalam keberlanjutan dengan spesifikasi pada batik tradisi. Urgensi penelitian ini adalah mengetahui dan mendeskripsikan peran keberlanjutan melalui penerapan kearifan lokal pada sebuah komunitas masyarakat untuk pelestarian batik tradisi, sehingga dapat dirumuskan solusi keberlanjutannya untuk jangka panjang.

\section{METODE PENELITIAN}

Pendekatan antropologis dengan sudut pandang etnografis dipergunakan untuk mengumpulkan dan menganalisis data penelitian ini secara kualitatif. Pemilihan pendekatan tersebut berdasarkan karakter permasalahan yakni mengetahui dan menguraikan peran kearifan lokal masyarakat Jawa yang dipergunakan untuk melestarikan batik tradisi di wilayah Girilayu. Sifat pendekatan antropologis menitikberatkan pada pengamatan terhadap perilaku dan cara berpikir masyarakat. Hal tersebut sesuai dengan tujuan penelitian ini untuk melihat upaya-upaya masyarakat Girilayu dalam melestarikan batik tradisi dengan sumber kearifan lokal setempat (Ihromi, 2006; Wiranata, 2011). Latar belakang pemilihan Girilayu sebagai lokasi penelitian karena memiliki akar sejarah kuat terkait keberadaan aktifitas membatik secara tradisional (batik tradisi) di desa tersebut, yang mendapat pengaruh dari Pura Mangkunagaran. Batik yang dihasilkan tidak menggunakan teknik modern seperti sablon (printing), malam dingin, dan digital; tetapi masih mempertahankan proses tulis atau serat dalam Bahasa Jawa; sehingga aktivitas membatik disebut nyerat, dan hasil membatik disebut seratan) (Elliot, 2004). Girilayu saat ini tengah mengalami krisis keberlanjutan pembatik berusia muda, kemudian berhasil bangkit perlahan dengan inisiatif para pembatik senior untuk menciptakan desain motif baru. Unsur kearifan lokal Girilayu tercermin pada nilai filosofis motif batik kontemporer yang dihasilkan. Masyarakat Girilayu masih teguh memegang ajaran Tri Dharma dari K.G.P.A.A. Mangkunagara I, yang berisi tentang mental untuk ikut memiliki (bertanggungjawab), membela atau mempertahankan keberlanjutan tradisi, serta hal-hal bersifat baik untuk kemaslahatan masyarakat luas, dan instropeksi (pengendalian diri) (Purwadi, 2007).

Pengumpulan data dilakukan dengan teknik wawancara, observasi, dan dokumen. Data yang diperoleh berasal dari wawancara mendalam dengan pembatik di Girilayu sebagai pelaku inisiasi desain motif baru. Referensi tentang sentra batik Girilayu masih minim, sehingga wawancara dengan pelaku atau perajin batik secara langsung adalah teknik tepat untuk memperoleh data akurat. Validitas data menggunakan validitas sumber dan data. Data yang diperoleh setelah melalui proses reduksi tersebut dikroscek 


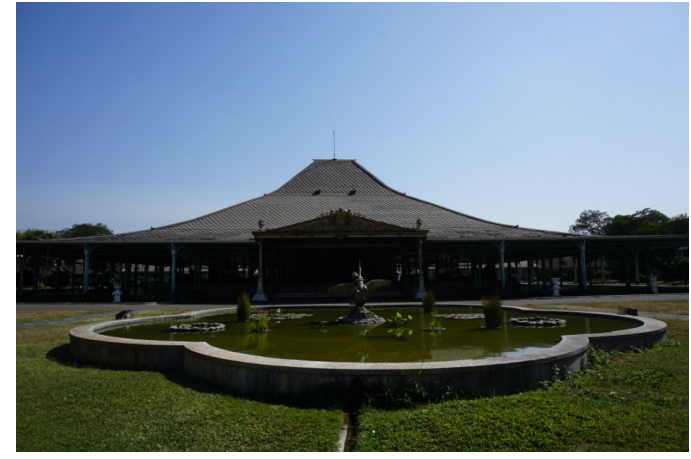

Gambar 1. Pura Mangkunegaran di Kota Surakarta atau Solo, salah satu pusat tahta kadipaten dengan wilayah kekuasaan setingkat keraton, hasil pembagian kekuasaan pada Perjanjian

Giyanti tahun 1755 dan Perjanjian Salatiga tahun 1757

(Sumber: Dokumentasi Desy Nurcahyanti, 2019)

kembali dengan pendapat dari tokoh masyarakat, pakar batik, peneliti lain dengan topik seputar Girilayu, dan referensi atau arsip serta dokumentasi yang relevan. Narasumber pelaku inisiasi desain motif baru dipilih berdasarkan kesepakatan kelompok, diwakili oleh pembatik yang mempraktikkan langsung proses pembuatan motif dengan sumber ide kearifan lokal Girilayu. Wawancara tidak hanya menggali informasi seputar pembuatan motif baru, tapi juga terkait dasar penggunaan kearifan lokal Girilayu untuk membuat motif batik baru, yang mampu menggugah semangat generasi mudah untuk melanjutkan batik tradisi. Hasil penelitian dideskripsikan sebagai jawaban dari rumusan permasalahan. Analisis referensif dilakukan dengan mencari faktor ketersinggungan dan kesesuaian antara upaya regenerasi yang sedang giat dilakukan oleh pembatik Girilayu dengan pendapat pakar maupun data pustaka. Hasil penelitian berupa langkah-langkah yang dilakukan oleh pembatik terkait pelestarian batik tradisi dengan kearifan lokal disajikan berupa bagan.

\section{ANALISIS DAN INTERPRETASI DATA}

Kearifan lokal masyarakat Jawa memiliki beragam bentuk penerapan dan cara penyampaian. Implementasinya berupa tata nilai, perilaku melalui komunikasi verbal (berbicara) atau non verbal (melalui sistem atau simbolisasi pada benda pakai sehari-hari seperti busana, gaya hunian, dan pemilihan alat transportasi). Masyarakat Jawa memperoleh pendidikan dan pembelajaran pola asuh secara tidak langsung yang bersifat tradisional (turun temurun) untuk mengedepankan sopan santun dan budi pekerti. Terlihat dari cara berkomunikasi yang menggunakan istilah khusus (tidak langsung) dan memposisikan diri dalam masyarakat bukan sebagai pusat perhatian. Ungkapan-ungkapan khusus digunakan dalam berkomunikasi untuk memperhalus bahasa dan tidak menyinggung lawan bicara. Pemakaian ungkapan tersebut biasanya untuk memberi nasehat atau mengkoreksi sikap negatif orang lain secara bijak. Bicara dengan suara pelan, tubuh yang sedikit membungkuk ke-

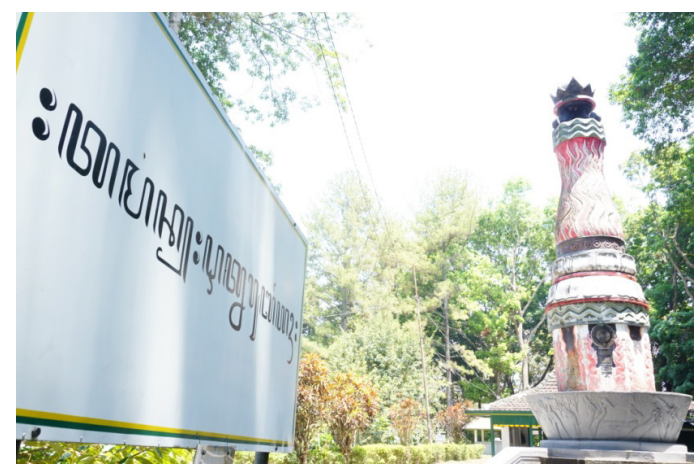

Gambar 2. Monumen Tri Dharma yang dibangun oleh Yayasan Mangadeg tahun 1971, dalam kompleks Astana Mangadeg yakni makam Kanjeng Gusti Pangeran Adipati Arya Mangkunagara I atau Pangeran Samber Nyawa sampai dengan III beserta keluarga dan keturunannya (Sumber: Dokumentasi Desy Nurcahyanti, 2019)

tika berjalan,dan pandangan menunduk atau terkadang tidak menatap lawan bicara secara langsung terutama yang lebih tinggi strukturnya secara usia maupun jabatan merupakan ciri bahasa tubuh masyarakat Jawa. Khusus untuk daerah Yogyakarta dan Surakarta yang memiliki kerajaan besar, kearifan lokal dalam sikap dan tata nilai berkiblat pada aturan kerajaan. Masyarakat Jawa di wilayah tersebut menganggap bahwa keraton merupakan pusat budaya, beradaban, dan tata aturan yang layak diadopsi untuk kalangan rakyat biasa (lihat Gambar 1).Terdapat strata khusus dalam masyarakat Jawa yakni keturunan raja, golongan bangsawan/ningrat/priyayi, dan rakyat biasa/ kawula alit. Semakin rendah stratanya maka bahasa yang dipergunakan untuk berkomunikasi dengan golongan di atasnya akan semakin tinggi. Para rakyat biasa memiliki kebanggaan jika mereka bisa bekerja dan mengabdi untuk para priyayi serta keluarga raja; dengan istilah ngawulo (mengabdi). Abdi dalem adalah wujud sikap ngawulo para rakyat kecil tersebut. Berposisi paling bawah dalam strata masyarakat menyebabkan para kawula alit terbiasa dengan sikap tunduk (manut atau menurut dalam Bahasa Indonesia) dan mampu mengendalikan diri dengan baik (Kuntowijoyo, 2004). Sikap tunduk, setia, dan mengikuti peraturan tersebut merupakan wujud kearifan lokal yang kian hari terkikis kemajuan zaman. Beragam tawaran alternatif pada masyarakat Jawa untuk menyesuaikan perubahan, berhasil mengalihkan perhatian untuk tetap menjaga tradisi bernilai luhur.

Pembatik di Girilayu merupakan sekelompok masyarakat yang masih memposisikan diri untuk ngawulo (mengabdi) hingga saat ini.Sebagian besar warga yang tinggal di wilayah tersebut merupakan keturunan langsung dari juru kunci makam besar raja-raja Pura Mangkunagaran, yakni Astana Mangadeg (makam K.G.P.A.A. Mangkunagara I sampai dengan III) dan Astana Girilayu (makam K.G.P.A.A. Mangkunagara IV, V, VII, dan VIII). Jabatan abdi dalem kuncen atau juru kunci merupakan posisi yang baik dalam strata sosial masyarakat Jawa (lihat Gambar 


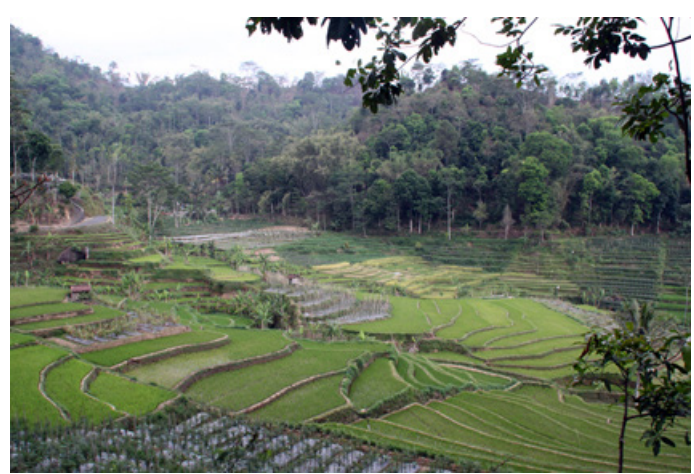

Gambar 3. Kondisi alam dan lingkungan di Girilayu pada siang hari.

(Sumber: Dokumentasi Desy Nurcahyanti, 2020)

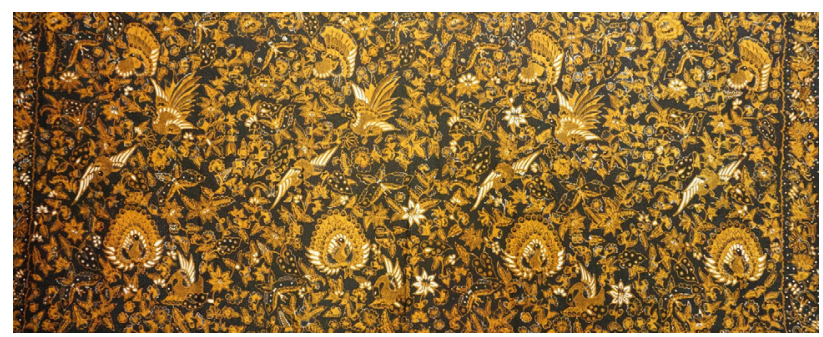

Gambar 4. Contoh kreasi pembatik generasi muda yang menghasilkan gaya kontemporer khas Batik Girilayu,

hasil kolaborasi gaya klasik Mangkunagaran (Surakarta) dengan ragam hias bentuk baru

(Sumber: Dokumentasi Desy Nurcahyanti, 2020)

2). Mereka di antara golongan priyayi dan kawula alit. Hanya orang berkompetensi dan memiliki rasa tanggungjawab tinggi yang mendapat kepercayaan tersebut.Rekomendasi jabatan berdasarkan saran dari kepercayaan raja, yang mengutus orang untuk mengamati para calon juru kunci makam.Terdapat beberapa aturan khusus bagi para juru kunci makam, salah satunya harus mampu menjaga informasi penting (rahasia) dari keluarga raja. Sampai dengan hari ini, masyarakat Girilayu masih memegang ajaran Mangkunagara I untuk merasa memiliki, menjaga (melestarikan), dan berani bertindak (untuk hal yang berguna). Ajaran tersebut terangkum dalam ajaran Tri Dharma atau tiga kebijakan untuk panduan sikap masyarakat dalam memposisikan diri secara individual serta komunal. Masyarakat terkadang menemui kesulitan untuk menentukan posisi diri, sehingga memerlukan kebijakan sebagai arah mengambil keputusan tepat. Tri Dharma tidak diajarkan sebagai bahan hafalan bagi masyarakat pembatik di Girilayu, tetapi terimplementasi secara nyata dalam kehidupan sehari-hari (lihat Gambar 2). Isi ajaran Tri Dharma tersebut antara lain: 1) Rumangsa melu handarbeni (merasa ikut memiliki), 2) Wajib melu hanggondeli (kewajiban ikut membela dan mempertahankan), dan 3) Mulat sarira hangrasa wani (Kesadaran untuk melakukan instropeksi) (Diskominfo, 2017).Tri Dharma saat ini telah terabstraksi sebagai kearifan lokal masyarakat Girilayu terutama para pembatik. Nilai-nilai ajaran tersebut secara jelas menuntun dan memberi arah untuk melanjutkan eksistensi batik tradisi. Upaya pembatik Girilayu menjaga keberlanjutan batik tradisi merupakan bentuk tanggungjawab moral masyarakat dan bentuk ngawulo atau pengabdian kepada bangsa di zaman sekarang.

Keberlanjutan, pelestarian dan regenerasi batik tradisi masih terus berjalan dan diupayakan konsistensinya sampai hari ini di Girilayu. Proses panjang dan hambatan dialami oleh pembatik senior yang mayoritas berusia lanjut menghasilkan cara menarik animo dari generasi muda untuk melanjutkan aktivitas batik tradisi. Hambatan terbesar adalah kesadaran untuk merasa memiliki, sebagaimana disebutkan pada poin satu ajaran Tri Dharma. Kesadaran ikut memiliki disebutkan paling awal karena hal tersebut berkaitan dengan moral dan mental kuat dilandasi dengan pemahaman, bahwa tradisi merupakan harta tak ternilai yang membentuk budaya dan struktur sosial di Girilayu. Terhentinya aktivitas batik tradisi merupakan stagnasi masyarakat Girilayu. Aktivitas yang telah dilakukan secara turun menurun selama puluhan tahun tersebut adalah nafas hidup yang mampu menghindarkan dampak negatif dari kemajuan zaman. Batik Girilayu merupakan bentuk sentra batik yang masih mempertahankan teknik tradisional untuk menghasilkan lembar kain kaya makna. Kegiatan membatik di Girilayu bukan untuk kepentingan industri yang menuntut kuantitas, tetapi menjaga kualitas dengan rangkaian proses tradisi sebagai bagian dari kontemplasi masyarakat, khususnya para perempuan pembatik. Perputaran ekonomi yang lamban dari batik Girilayu, menjadi salah satu penyebab keengganan generasi muda melanjutkan aktivitas tersebut.Batik Girilayu memiliki konsep istimewa karena bukan sebagai penopang hidup, tetapi sebagai sarana ekspresi, kontemplasi, dan rekreasiuntuk pembatik. Hasil karya yang belum laku, tidak menjadi soal bagi mereka, karena para pembatik tersebut memiliki keyakinan bahwa rejeki sudah diatur adil oleh Yang Maha Kuasa. Batik yang terjual berarti si kain telah menemukan jodohnya, sang pemilik. Kain batik dibuat sepenuh hati oleh tarian canting para pembatik tersebut. Sebaliknya, ketika masih terpajang indah di kayu display, berarti tengah menunggu sang pemilik sedang dalam perjalanan untuk menjemput.

Lokasi Girilayu yang sejuk dan dingin pada pagi serta malam hari, menyebabkan aktivitas luar rumah masyarakat terbatas pada siang hari (lihat Gambar 3). Dua waktu tersebut menjadi kesempatan para anggota keluarga untuk berkumpul.Waktu berkumpul dipergunakan oleh orang tua (pembatik senior) untuk berkomunikasi dengan anak-anak mereka. Salah satu topik yang dibicarakan adalah tentang aktivitas membatik dan rencana yang akan dilakukan pada hari berikutnya untuk membatik. Cara persuasif dan kekeluargaan tersebut menjadi efektif. Sifat afirmatif (pengulangan) menyebabkan anak-anak pembatik memiliki minat melanjutkan aktivitas membatik tradisi, sebagai bentuk ekspresi, kontemplasi, dan rekreasi guna melanjutkan ajaran-ajaran luhur dari pendahulu. Bekerjasama 
Bagan 1. Alur pengaruh kearifan lokal pada ajaran Tri Dharma dalam pelestarian batik tradisi di Girilayu

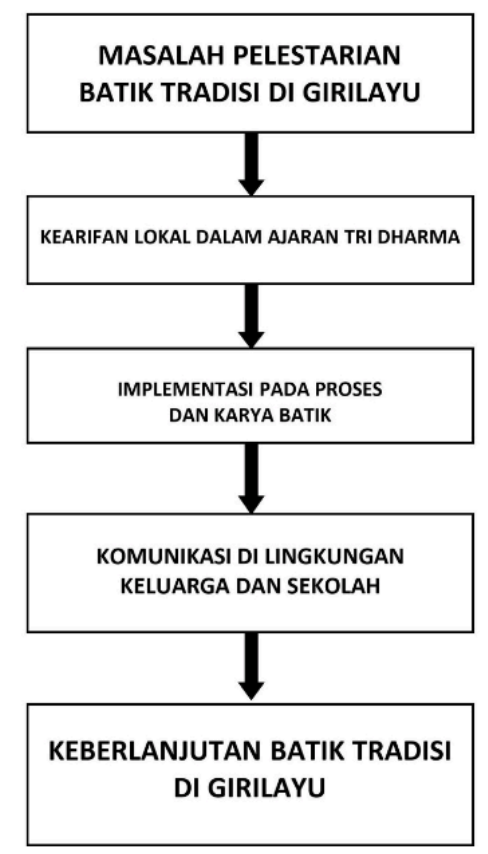

dengan pemerintah daerah dan dinas pendidikan setempat, aktivitas membatik dimasukkan dalam kurikulum sebagai kegiatan ekstra kurikuler rutin (lihat Bagan 1). Beberapa pertimbangan digunakan sebagai dasar mengangkat membatik sebagai kegiatan tambahan, yakni membantu olah motorik halus pada anak, meningkatkan konsentrasi, pengendalian emosi, meningkatkan kepekaan terhadap olah bentuk, menjaga koordinasi sikap tubuh, menanamkan rasa cinta pada seni tradisi, dan menstimulasi untuk berkreasi mencipta motif-motif kontemporer (lihat Gambar 4). Membatik juga melatih kesabaran, disiplin, dan keteraturan. Motif batik geometris misalnya, tidak boleh dibuat dengan melompat-lompat posisi sesuka hati, karena berpengaruh pada hasil akhir, tidak terlihat menyatu. Berdasarkan penuturan narasumber, pembatik yang sudah dapat menciptakan irama dalam mencanting kain, mampu memiliki daya imajinasi terhadap hasil akhir batikannya, baik/kurang secara estetik. Sinergi serta kolaborasi antara keluarga dan pihak sekolah berikut elemen masyarakat (pemerintah) merupakan daya dorong yang baik untuk keberlanjutan batik tradisi (lihat Bagan 1). Batik tradisi di Girilayu menjadi media tepat untuk menghidupkan peran kearifan lokal pada nasehat sehari-hari masyarakat Girilayu dan tiga ajaran kebijakan hidup dari K.G.P.A.A. Mangkunagara I, yang abadi dan relevan dengan kondisi terkini.

\section{SIMPULAN}

Temuan penelitian ini adalah rumusan cara pelestarian batik tradisi di Girilayu dengan kekuatan efektifitas peran kearifan lokal masyarakat bersumber ajaran luhur Mangkunagara I (adipati atau pemimpin setingkat di bawah raja dari Pura Mangkunagaran). Tri Dharma tidak hanya berisi ajaran yang bernilai filosofis, tetapi menyangkut dimensi mikrokosmos untuk tiap-tiap individu masyarakat Girilayu, serta makrokosmos di luar aktivitas membatik. Pada perkembangannya batik tradisi di Girilayu membentuk dirinya sendiri dalam format kearifan lokal khas Girilayu. Batik menjadi media untuk membentuk hubungan sosial dan komunikasi yang baik. Topik yang ringan namun memiliki muatan budaya sebagai identitas sebuah negara besar bernama Indonesia adalah batik. Masyarakat menjadi bukti pola pikir anti arus utama yang memposisikan batik sebagai komoditas ekonomi dan aktivitas penopang hidup. Batik tradisi Girilayu merupakan sarana eskpresi, kontemplasi, dan rekreasi bagi masyarakat. Pengisi waktu luang di antara aktivitas sehari-hari yang padat. Sifat kontemplatif pada batik dimanfaatkan oleh sebagian besar pembatik untuk solusi permasalahan. Para perajin mampu mengendalikan emosi dan berpikir jernih untuk menyelesaikan masalah dengan membatik. Gerakan halus dan teratur mempengaruhi pelakunya untuk menjaga sikap agar tidak mengganggu ritme visualisasi ide menjadi motif batik. Kestabilan yang terjaga akan mempengaruhi hasil akhir batik. Oleh sebab itu, proses batik berkualitas tinggi memerlukan waktu pengerjaan relatif lama, antara 2-3 bulan untuk satu lembar kain.

Nilai-nilai positif pada batik tradisi merupakan sarana efektif untuk menanamkan nilai-nilai ketekunan, disiplin, dan kesabaran. Tiga nilai tersebut menjadi modal dasar utama bagi generasi muda penerus aktivitas membatik tradisi. Usia dini dianggap tepat untuk melakukan upaya pelestarian. Pada usia tersebut anak hanya dituntut untuk mampu menguasai permainan dan tunduk pada aturan, sehingga masih terbuka ruang pada pola pikirnya untuk diafirmasi memori yang baik tentang pelestarian tradisi. Kunci keberhasilan regenerasi adalah pendekatan dan cara yang tepat untuk menyampaikan maksud, hingga tumbuhnya kesadaran serta inisisasi untuk melakukan tindakan nyata. Kearifan lokal masyarakat Jawa yang paling utama adalah kemampuan untuk beradaptasi menyesuaikan kemajuan zaman dan tetap menjaga sikap. Peran kearifan lokal masyarakat Jawa dalam hal kemampuannya melestarikan batik tradisi yakni menumbuhkan kesadaran untuk merawat budaya, melalui pendekatan persuasif melalui nasehat, ajaran, nilai serta norma. Keterkaitan antara kearifan lokal dan nilai tradisi adalah berbanding lurus. Kearifan lokal yang terjaga dan masih dimanfaatkan oleh masyarakat sebagai panduan hidup otomatis terlihat dari implementasinya pada bentuk seni tradisi, dan sebaliknya. Pendekatan antropologi untuk menggali data dari masyarakat terkait aktivitas pelestarian batik tradisi di Girilyu adalah tepat, karena membebaskan masyarakat untuk memberikan beragam informasi mengalir dari berbagai perspektif. Kelemahan pendekatan ini adalah masyarakat memiliki bahasa tersendiri, sehingga kemampuan analisis dan interpretasi yang baik diperlukan guna menyajikan data dengan validitas baik. Penelitian ini masih memili- 
ki peluang untuk dikembangkan dengan lokasi penelitian berbeda menggunakan tahapan yang sama. Lokasi berbeda akan menghasilkan variasi hasil berbeda. Hal tersebut disebabkan beragam faktor, terutama peraturan khusus yang berlaku di suatu wilayah.

\section{UCAPAN TERIMA KASIH}

Ucapan terima kasih penulis tujukan kepada:

1. Seluruh anggota kelompok Perajin Batik di Sentra Batik Girilayu, Karanganyar, Jawa Tengah yang telah bekerjasama dan mengizinkan penulis untuk meneliti, serta mempublikasikan hasil temuan tentang upaya keberlanjutan batik tradisi di wilayah tersebut.

2. Prof. Dr. Dharsono, M.Sn., Guru Besar Estetika Nusantara dari Institut Seni Indonesia Surakarta, yang bersedia meluangkan waktu memberi pengetahuan dan informasi berharga terkait batik Karanganyar dan Girilayu, sehingga dapat dipergunakan untuk melengkapi data penelitian ini.

3. Dr. Susanto, M.Hum., Dosen dan Sejarawan dari Program Studi Ilmu Sejarah, Fakultas Ilmu Budaya Universitas Sebelas Maret; yang telah memberikan referensi tentang sejarah Girilayu, sehingga sajian data penelitian dapat tersusun baik.

\section{DAFTAR RUJUKAN}

Adnyani, N. W. Giri. (2017), Batik: The Colors of Life. Jakarta: Kementerian Pariwisata Republik Indonesia.

Amanda, Irine Carissa Desmaristi. (2018), "Identifikasi Bentuk-bentuk Kearifan Lokal dalam Sistem Religi Masyarakat Situs Sangiran Studi Kasus di Kecamatan Gondangrejo, Karanganyar", in the Jurnal Sangiran, VII/1, Balai Pelestarian Situs Manusia Purba Sangiran, Sragen.

Astuti D., Siti Irene. (11 ${ }^{\text {th }}$ July 2012), “Kearifan Lokal sebagai Modal Sosial dalam Pendidikan Karakter di Sekolah", in the Seminar Nasional Ilmu Pendidikan Program Studi Ilmu Pendidikan Program Pascasarjana Universitas Negeri Makasar, at Gedung AD Lantai 5 PPs UNM.

Budiyono \& Yoga Ardian Feriandi. (27 $7^{\text {th }}$ April 2017), "Menggali Nilai-nilai Kearifan Lokal Budaya Jawa sebagai Sumber Pendidikan Karakter", in the Seminar Nasional Bimbingan dan Konseling, Program Studi Bimbingan dan Konseling FKIP Universitas PGRI Madiun.

Cynthia, Ida \& Dedi Alfiandri. (2011), Dampak Kekuatan Budaya Indonesia dalam Industri Kreatif, Global Citra Media, Jakarta.

Diskominfo. (29 September 2017), Tugu Tri Dharma, Infografik Kabupaten Karanganyar, http:/www.karanganyarkab.go.id/20170929/tugu-tridharma/.
Elliot, Inger McCabe \& Brian Brake. (2004), Batik:Fabled Cloth of Java, Periplus, New York, United Kingdom.

Endraswara, Suwardi. (2018), Falsafah Hidup Jawa: Menggali Mutiara Kebijakan dari Intisari Filsafat Kejawen, Cakrawala, Yogyakarta.

Fajarini, Ulfah. (March 2014) "Peranan Kearifan Lokal dalam Pendidikan Karakter", in the Sosio Didaktika: Social Science Education Journal, I/ 2, Faculty of Educational Science UIN (State Islamic University) Syarif Hidayatullah Jakarta, Jakarta.

Herdiana, Uung Runalan Soedarmo, \& Yadi Kusmayadi. (2020), Motif Ragam Hias dan Nilai-nilai Filosofis Batik Ciamis, in the Jurnal Artefak, VII/1, Program Studi Pendidikan Sejarah Fakultas Keguruan dan Ilmu Pendidikan Universitas Galuh, Ciamis.

Ihromi, T. O. (2004), Pokok-pokok Antropologi Budaya, Yayasan Obor Indonesia, Jakarta.

Inawati, Asti. (2014), "Peran Perempuan dalam Mempertahankan Kebudayaan Jawa dan Kearifan Lokal" Musâwa,XIII/2, Pusat Studi Wanita UIN Sunan Kalijaga Yogyakarta, Yogyakarta.

Kristie, Sella, Tessa Eka Damayanti, \& Sriwinarsih Maria Kirana. (2019), "Makna Motif Batik Parang sebagai Ide dalam Perancangan Interior", in the AKSEN Journal of Design and Creative Industry, III/2, Interior Architecture Department Ciputra University, Surabaya.

Kuntowijoyo. (2004), Raja, Priyayi, dan Kawula: Surakarta 1900 - 1915, Ombak, Yogyakarta.

Mardikantoro, Hari Bakti. (2013), "Bahasa Jawa sebagai Pengungkap Kearifan Lokal Masyarakat Samin di Kabupaten Blora", in the Komunitas: International Journal of Indonesian Society and Culture, V/2, Department of Sociology and Anthropology, Faculty of Social Sciences, State University of Semarang, Semarang.

Mulder, Niels. (2005), Mysticism in Java: Ideology in Indonesia, Pustaka Pelajar, Yogyakarta.

Ningsih, Zain Rochmati. (2018), "Kearifan Lokal Masyarakat Jawa dalam Novel Genduk Sundari Mardjuki (Kajian Antropologi Sastra)", in the Jurnal Mahasiswa Unesa, I/1, Program Studi Pendidikan Bahasa dan Sastra Indonesia, Jurusan Bahasa dan Sastra Indonesia Fakultas Bahasa dan Seni Universitas Negeri Surabaya, Surabaya.

Pramono, Kartini. (2013), "Nilai Kearifan Lokal dalam Batik Tradisional Kawung", in the Jurnal Filsafat, XXIII/2, Fakultas Filsafat Universitas Gadjah Mada, Yogyakarta. 
Purwadi. (2005), Upacara Tradisional Jawa: Menggali Untaian Kearifan Lokal, Pustaka Pelajar, Yogyakarta.

(2007), Sistem Pemerintahan Kerajaan Jawa Klasik, Pujakesuma.

Qiram, Ikhwanul, Buhani, \& Gatut Rubiono. (2018), “Batik Banyuwangi: Aesthetic and Technical Comparison of Coastal Batik", in the Lekesan Interdiciplinary Journal of Asia Pasific Arts, I/2, Institut Seni Indonesia Denpasar, Bali.

Suarta, I Made. (2018), "Nilai-nilai Filosofis Didaktis, Humanistis, dan Spiritual dalam Kesenian Tradisional Macapat Masyarakat Bali”, in the MUDRA Jurnal Seni Budaya, XXXIII/2, Institut Seni Indonesia Denpasar, Bali.

Suminto, R. A. Sekartaji. (2015), "BATIK MADURA: Menilik Ciri Khas dan Makna Filosofinya", in the CORAK Jurnal Seni Kriya, IV/1, Institut Seni Indonesia Yogyakarta, Yogyakarta.

Situngkir, Hoki. (2016), Kode-kode Nusantara, Exposé, Jakarta Selatan.

Tabrani, Primadi. (2012), Bahasa Rupa, Kelir, Bandung.

Wahida, Adam, Endang Sri Handayani, \& Slamet Supriyadi. (2020), "The Philoshopical Values of Kawung Batik Motif in Contemporary Batik Painting", in the MUDRA Jurnal Seni Budaya, XXXV/1, Institut Seni Indonesia Denpasar, Bali.

Widodo, Wahyu. (2018), Mantra Kidung Jawa: Mengurai yang Lingual hingga Transendental, UB Press, Malang.

Wiranata, I Gede A. B. (2011), Antropologi Budaya, PT Citra Aditya Bakti, Bandung. 